\title{
Chemical mobility and bioavailability of sediment-bound heavy metals influenced by salinity
}

\author{
W. Calmano, ${ }^{1}$ W. Ahlf ${ }^{1}$ \& J.-C. Bening ${ }^{2}$ \\ ${ }^{1}$ Technische Universität Hamburg-Harburg, Eissendorfer Str. 40, D-2100 Hamburg 90, Germany; \\ ${ }^{2}$ Institut für Hydrobiologie und Fischereiwissenschaft, Zeiseweg 9, D-2000 Hamburg 50, Germany
}

Key words: heavy metals, sediments, bioavailability, transfer processes, mobilization, salinity

\begin{abstract}
The transfer of metals from contaminated sediments to algal cell walls (Scenedesmus quadricauda) and organisms from various trophic levels (euryhaline osmoconform hydroid Cordylophora caspia and algae Brachiomonas submarina) was studied with a multichamber device. The system consists of a central chamber which contained the mud suspension and six external chambers containing the different biological indicators. The solids in the central and external chambers are separated by $0.45 \mu \mathrm{m}$-diameter membranes which allow diffusion of the mobilized, dissolved metal compounds. Experiments were performed with dredged sediments at various salinities $(0.5,1.0,1.5$, and 2.0 percent, respectively) and the kinetic of re-adsorption was obtained by taking samples after different time intervals. High enrichment of $\mathrm{Cd}$ was found in the living alga Brachiomonas submarina, but on the other side only a weak influence of salinity on re-adsorption could be observed. Model experiments with ionic Cd showed a clear dependency on Cd-sorption on the algae, Cd-concentration in solution, and salinity. These results indicate that the transfer of metals mainly depends on the specific surface properties of the substrates and on the specific chemical form of the dissolved mobilized metal.
\end{abstract}

\section{Introduction}

It is a general experience that most water quality data for heavy metals rarely reflect the possible adverse influences on aquatic biota. There are various explanations for this experience. One is the lack of knowledge of the critical metal species, combined with difficulties in speciation analysis. Another reason is that there are some mechanisms of interactions between organisms and their environment which are not necessarily restricted to the direct uptake of metals from the water phase. There are many indications that - for understanding of these mechanisms - it is important to include the solid phase (sediments, sus- pended matter) in such systems and to study the interactions, particularly under changing environmental conditions.

Mobilization and transfer of heavy metals from contaminated sediments to aquatic organisms are important factors in the ecological evaluation of dredging activities. Resuspension, transport into estuarine and marine ecosystems and disposal of dredged material into seawater are attended by changes of redox-, pH-, and salinity-conditions. Alterations of these physico-chemical conditions may gradually change some controlling solid compounds $\left(\mathrm{Fe}^{2+} / \mathrm{Fe}^{3+}, \mathrm{Mn}^{2+} / \mathrm{Mn}^{4+}\right.$, $\left.\mathrm{S}^{2-} / \mathrm{SO}_{4}^{2-}\right)$, thus changing the solubility of certain metals. Mobilized metals may be re-adsorbed on 
various, reactive sediment components with different and competitive behaviour in sorption characteristics like clays, detrital organic matter, iron and manganese (hydr)oxides, carbonates, sulfides and algae, bacteria or other living cells. Heavy metal associations on sediment particles are the product of these interactive processes.

The aspect of solid concentration deserves particular attention, since experimental observations of the sorption/complexation characteristics of metals with e.g. humic type substances (Gamble et al., 1980), algal cell walls (Förstner et al., 1984), and hydrous metal oxides (Benjamin \& Leckie, 1981; Leckie, 1986) have revealed variations in binding intensity as a function of the degree of site occupancy. In comparison to the different types of solids the dominant role of biological substrates in the binding of heavy metals is of particular relevance for the transfer of these elements.

\section{Preliminary studies}

In previous studies (Calmano et al., 1988a, b; Förstner et al., 1989) we introduced a multichamber system that permits the simultaneous study of sorption/desorption and metal transfer reactions on major sedimentary constituents like clay minerals, Fe-oxides, Al-oxide, Mn-oxide, quartz, and algal cell walls. In this section the

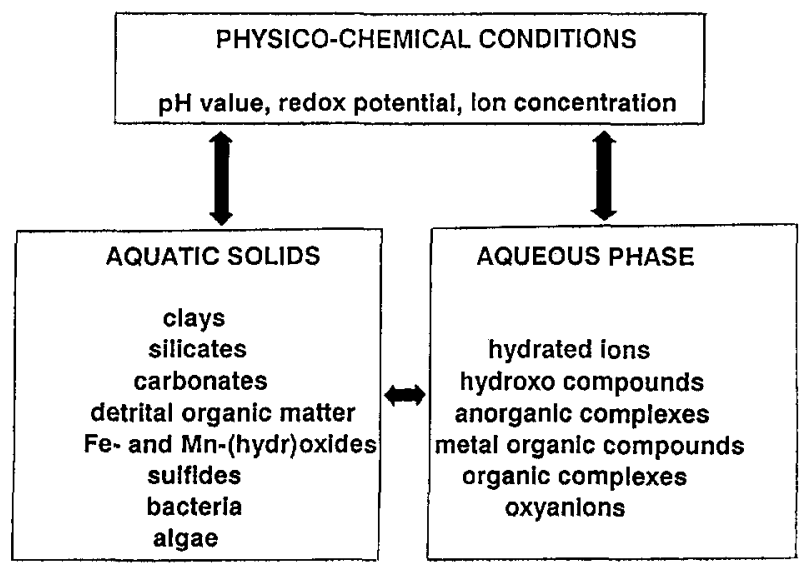

Fig. 1. Physico-chemical interactions and metal species in aquatic systems. essential results of seawater influence and redox potential changes on dredged material from the Elbe River and on the interactions between these model components are summarized.

The laboratory system used in these studies (Fig. 2) is composed of a central chamber connected with six external chambers which are separated by membranes of $0.45 \mu \mathrm{m}$ pore diameter. The volume of the central chamber is about 6 litres and each of the external chambers has a volume of $500 \mathrm{ml}$. The solids are kept in suspension by magnetic stirring.

In these experiments the original sediment was placed in the central chamber, and the model sediment components were arranged around in the external chambers. The quantities of the model
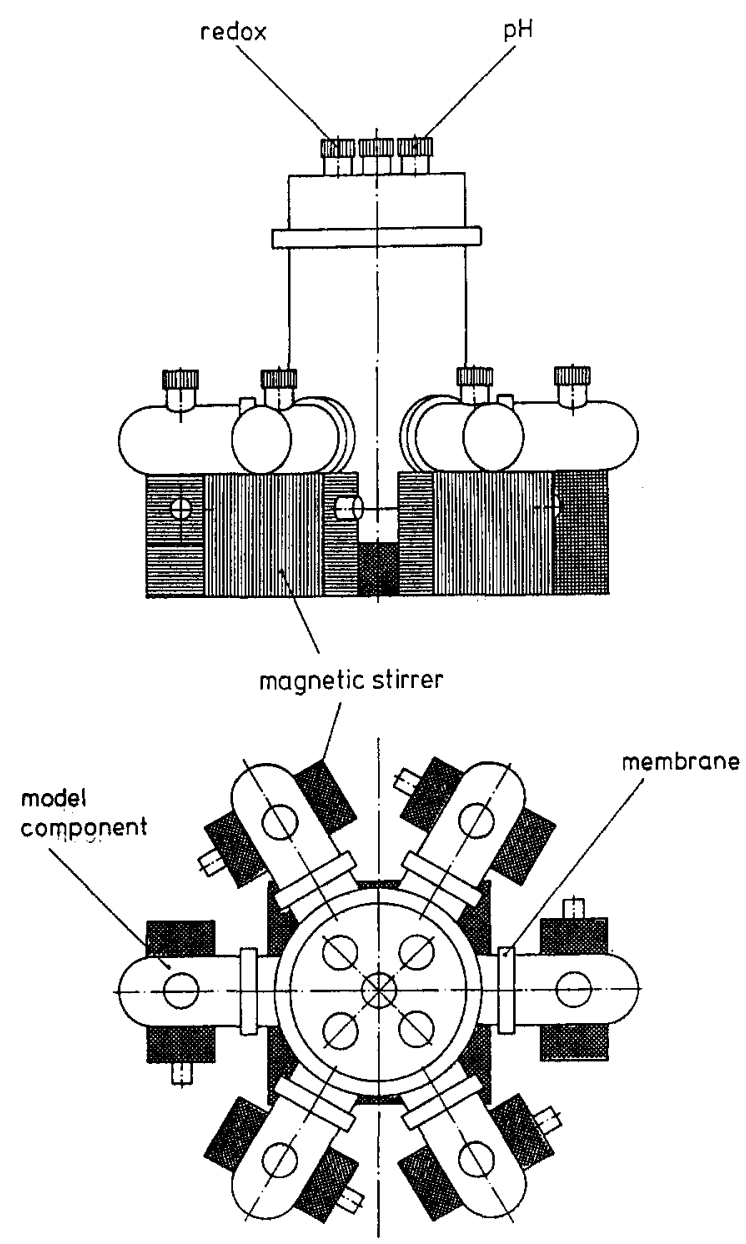

Fig. 2. Schematic view of the multichamber device. 
components were chosen to simulate an average sediment composition. As shown in Fig. 3a we found a significant remobilization of cadmium and also of other metals by seawater from dredged freshwater sediments. On the other side the metals were strongly enriched on algal cell walls, in particular an element like copper (see Fig. 3b). Under anoxic conditions metal concentrations in solution were generally low and the transfer to the single model sediment components limited. After oxidation of the sediment suspension, dissolved concentrations of all metals were distinctly higher and the same could be observed on the model solids. Such information is needed in practice to predict the possible implications of dredging processes in rivers and estuaries, when anoxic sediments are resuspended or redeposited in oxic water, and of dumping dredged material from freshwater into coastal waters.

\section{Methods and materials}

In previous studies we generally found high enrichments of metals on algal cell walls. Now we want to study the transferability of these results to living material. Therefore the present study deals with the competitive uptake of heavy metals from a contaminated sediment on three bioindicators in our multichamber system:

- cell wall material of the alga Scenedesmus quadricauda,

- the living halotolerant alga Brachiomonas submarina, and

- the euryhaline hydroid Cordilophora caspia.

Biological material may be involved in metabolic processes and thus may constitute the major carriers by which metals are transferred within the foodchain.

The central chamber contained the original dredged mud $(1.2 \mathrm{~kg}=500 \mathrm{~g}$ dry weight from Hamburg Seehafen; grain size: $85 \%<0.63 \mu \mathrm{m}$; $\mathrm{pH}:$ 7.5). The content of some heavy metals are listed in Table 1.

To study the influence of salinity on metal uptake by the three bioindicators the system containing the sediment in the central chamber was
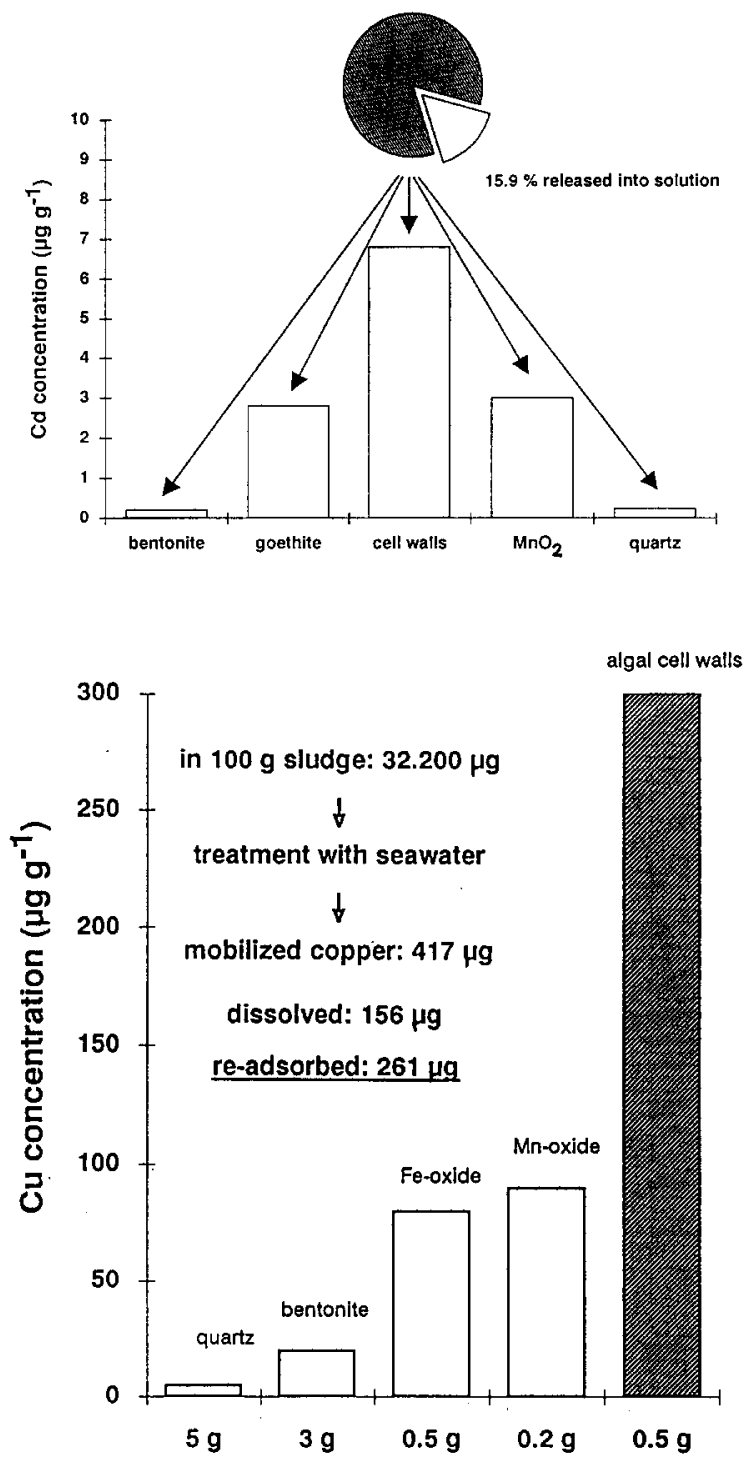

Fig. 3a. Mobilization of $\mathrm{Cd}$ from anoxic freshwater sediments and transfer to different model substrates after treatment with seawater.

Fig. 3b. Mobilization of $\mathrm{Cu}$ from anoxic freshwater sediments and transfer to different model substrates after treatment with seawater.

Table 1. Heavy metal contents [ $\mathrm{mg} \mathrm{kg}^{-1}$ ] of the studied sediment.

\begin{tabular}{lllllll}
\hline As & $\mathrm{Cd}$ & $\mathrm{Cr}$ & $\mathrm{Cu}$ & $\mathrm{Hg}$ & $\mathrm{Pb}$ & $\mathrm{Zn}$ \\
\hline 74 & 9.5 & 193 & 332 & 9.9 & 126 & 1948 \\
\hline
\end{tabular}


filled with water of different salinities $(0.2 \%$, $0.8 \%, 1.5 \%$ ) and equilibrated with the external chambers for $16 \mathrm{~h}$. Then in each of two of the external chambers suspensions (100 mg dry weight) of the respective algae and hydroids were prepared and samples taken and analyzed after various time intervals $(0.5 \mathrm{~h}, 1 \mathrm{~h}, 2 \mathrm{~h}, 4 \mathrm{~h}, 6 \mathrm{~h})$.

\section{Results and discussion}

Figure 4 shows the sorption curves of $\mathrm{Cd}, \mathrm{Zn}, \mathrm{Cu}$, and $\mathrm{Mn}$ on Brachiomonas submarina (a), cell walls
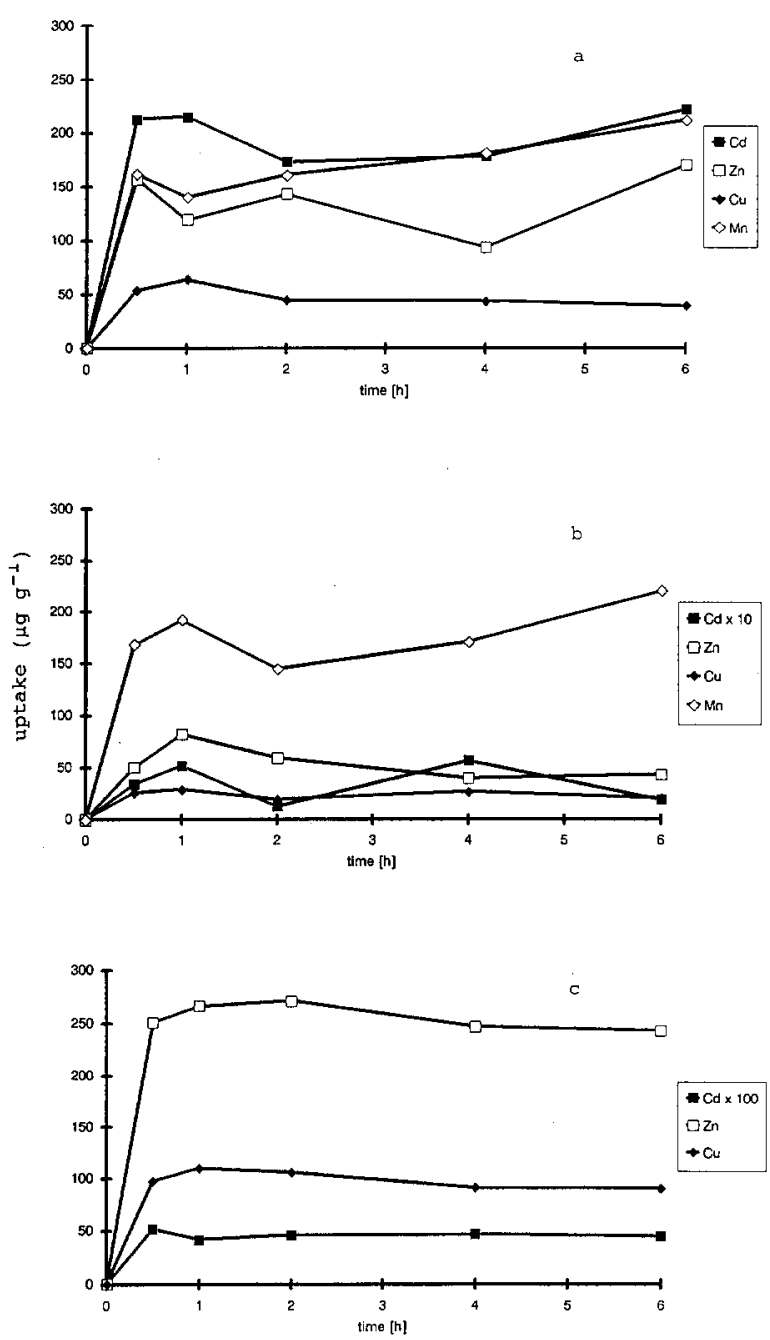

Fig. 4. Uptake of $\mathrm{Cd}, \mathrm{Zn}, \mathrm{Cu}$, and $\mathrm{Mn}$ from polluted sediments in 3 bioindicators at $15 \%$ salinity. of Scenedesmus quadricauda (b), and Cordilophora caspia (c) at $1.5 \%$ salinity. The initial metal concentration in all experimental particulate materials were low and are represented by the point at time 0 . Given are the metal concentrations in the solids. In our experiment the equilibrium concentrations of dissolved metals are of minor interest because the uptake not only depends on the total metal concentration in solution but also on the chemical form of the metal species and nature and size of the materials surface (Ahlf, 1988).

Generally the sorption took place in relatively short time intervals. Except for $\mathrm{Cd}$, which showed a decreasing sorption tendency at $0.2 \%$ salinity, the curves had a constant trend over the time in all other cases. Surprisingly was the strong enrichment (about factor 100) of $\mathrm{Cd}$ on the living alga Brachiomonas submarina at all salinities. $\mathrm{Zn}$ and $\mathrm{Cu}$ were strongly sorbed by the hydroids Cordilophora caspia. This leads to the conclusion that these organisms do not have effective active mechanisms preventing the uptake of heavy metals.

The Fig. 5a-c show the sorption of metals as a function of salinity. For Cd (Fig. 5a) only the hydroids showed a small decreasing trend with increasing salinity. The same could be observed for the uptake of $\mathrm{Zn}$ in Brachiomonas submarina (Fig. 5b). Cu showed a distinct decreasing trend with increasing salinity for Brachiomonas submarina and the hydroids (Fig. 5c).

To examine the surprising high uptake of $\mathrm{Cd}$ in the living alga Brachiomonas submarina we carried out sorption experiments with ionic $\mathrm{Cd}$ and this alga. A certain amount (cell number $=5 \times 10^{6} /$ $50 \mathrm{ml}$ ) of the alga was shaken for $12 \mathrm{~h}$ in solutions of different salinities $(0.5 \%, 1 \%, 1.5 \%, 2 \%)$ and at various $\mathrm{Cd}$ concentrations $(0.5,1,1.5$, $2 \mathrm{mg} \mathrm{l}^{-1}$ ) at $\mathrm{pH}=7.5$.

Figure 6 shows the sorption isotherms. There is a clear dependency on sorption of $\mathrm{Cd}, \mathrm{Cd}$-concentration in solution, and salinity. The lower the salinity the higher the Cd-enrichment on the algae, and the sorption increases with increasing $\mathrm{Cd}$ concentrations in solution. These results could be expected and may be due to the species distribution of $\mathrm{Cd}$ in solution. 


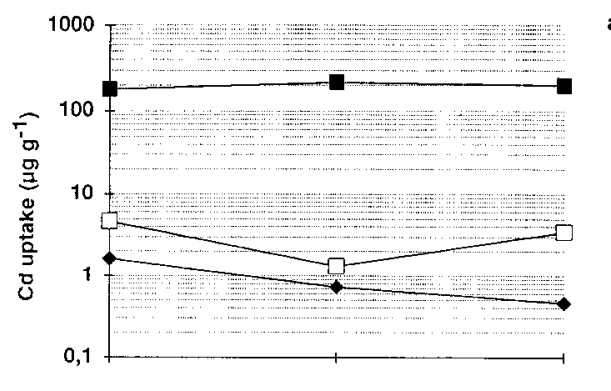

a
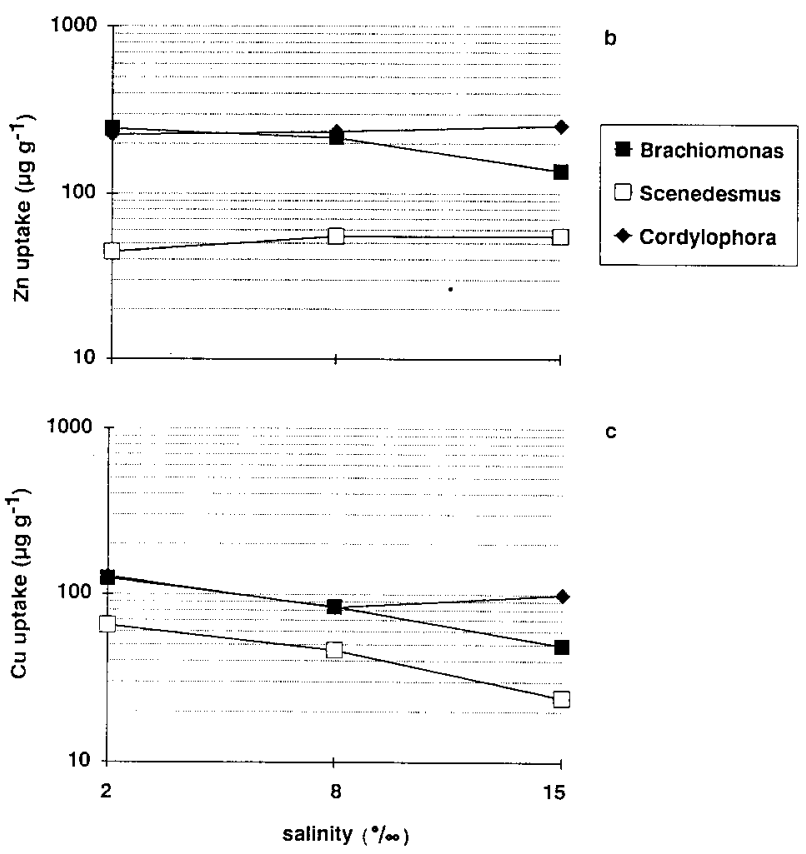

Fig. 5a-c. Uptake of $\mathrm{Cd}, \mathrm{Zn}$, and $\mathrm{Cu}$ from sediments in living algae (Brachiomonas submarina), algal cell walls (Scenedesmus quadricauda), and hydroids (Cordylophora caspia) at different salinities.

As can be calculated by the use of stability constants the most frequently existing species at low salinity are the positively charged $\mathrm{Cd}^{2+}$ and the mono-chloro-Cd-complex (see Table 2). With increasing salinity the positively charged species decrease and the neutral or negatively charged species increase. This changing species distribution in solution has of course a direct influence on the Cd-sorption on the negatively charged algal surface. Apart from stronger competition of positive alkali ions, the reason of reduced Cd sorption at higher salinities may be this change in charge of the dissolved Cd-species.

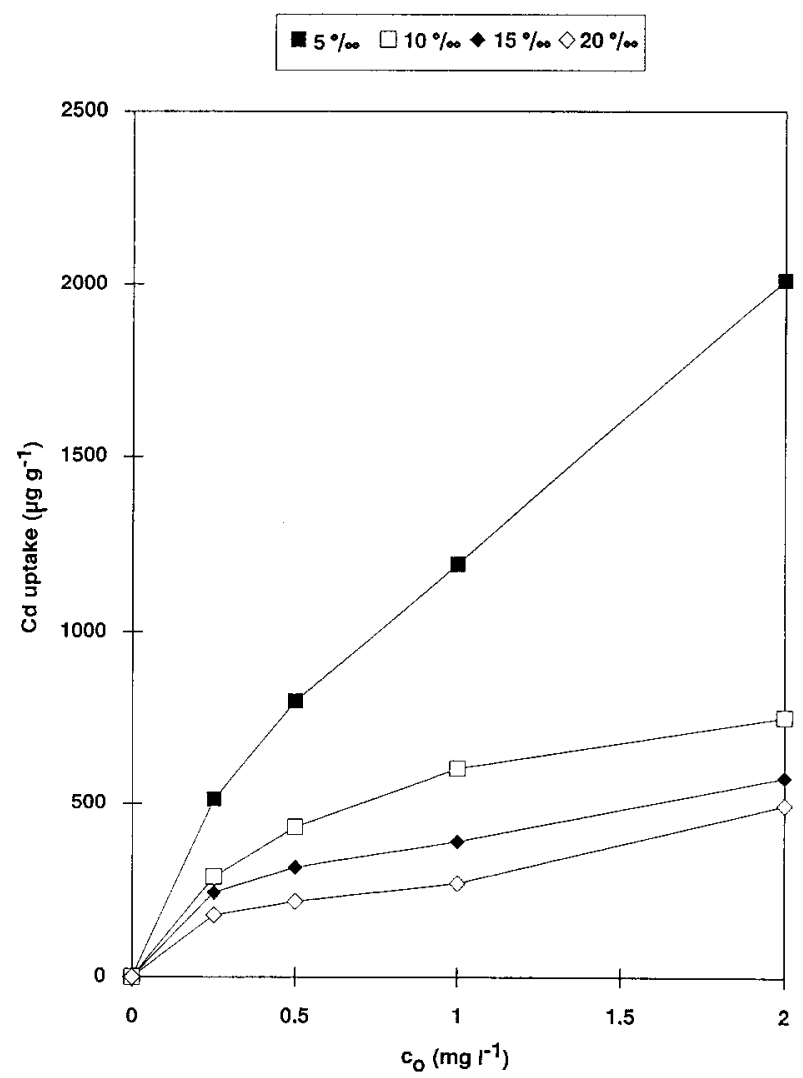

Fig. 6. Sorption of $\mathrm{Cd}^{2+}$ on Brachiomonas submarina at different salinities.

Table 2. Calculated Cd-species distribution $[\%]$ at different salinities.

\begin{tabular}{lrrrr}
\hline $\mathrm{Cd}^{2+}$ & 19.63 & 11.43 & 7.65 & 5.41 \\
\hline$[\mathrm{CdCl}]^{+}$ & 65.46 & 61.97 & 55.95 & 49.71 \\
{$\left[\mathrm{CdCl}_{2}\right]$} & 13.74 & 22.15 & 29.40 & 33.44 \\
{$\left[\mathrm{CdCl}_{3}\right]^{-}$} & 0.72 & 2.37 & 4.42 & 6.56 \\
{$\left[\mathrm{CdCl}_{4}\right]^{2-}$} & 0.12 & 0.84 & 2.39 & 4.72 \\
{$[\mathrm{CdCl}(\mathrm{OH})]$} & 0.21 & 0.19 & 0.17 & 0.15 \\
$\begin{array}{l}\text { Positively } \\
\text { charged species }\end{array}$ & 85.1 & 73.4 & 63.6 & 55.1 \\
$\begin{array}{l}\text { Neutral or nega- } \\
\quad \text { tively charged } \\
\text { species }\end{array}$ & 14.9 & 26.6 & 36.4 & 44.9 \\
\hline
\end{tabular}

But these effects could not be observed in those experiments in the multichamber system, where $\mathrm{Cd}$ had been mobilized from polluted dredged sediments (see Fig. 5a-c). Cd from dredged mud 
reacted otherwise than ionic $\mathrm{Cd}$. The reasons for it could be that

- the pore water of the sediment suspension contains a lot of dissolved organic ligands by which $\mathrm{Cd}$ is complexed;

- these organic complexed $\mathrm{Cd}$ has a high affinity to the organic surfaces of the biological material, so that increasing salinity does not prevent sorption on the algal surfaces and causes no remobilization effects, respectively.

\section{Conclusion}

These and former experiments have shown that heavy metals are mobilized from polluted sediments if they are exposed to changing environmental conditions like oxidation of anoxic muds, decreasing $\mathrm{pH}$ values, or increasing salinity. In natural systems with high particle concentrations, heavy metals bound on sediment components with lower binding intensities are transferred to such with strong binding intensities like biological surfaces. Probably the re-adsorption mainly depends on the specific surface properties of the substrates and on the specific chemical form of the dissolved mobilized metal, e.g. if it is complexed by anorganic or organic ligands or exists in an ionic form. As can be concluded from the results of the kinetic experiments the uptake or re-adsorption is only a passive and not an active process. Such experimental results are the base for more realistic models in metal transfer. The priorities in further studies should therefore lie in more detailed examinations of the dissolved and solid metal species in such natural systems.

\section{References}

Ahlf, W., 1988. Transfer of heavy metals from suspended sediments to the alga Stichococucus bacillaris in an estuarine water medium. Wat. Sci. Tech. 20: 33-38.

Benjamin, M. M. \& J. O. Leckie, 1981. Multiple site adsorption of $\mathrm{Cd}, \mathrm{Cu}, \mathrm{Zn}$, and $\mathrm{Pb}$ on amorphous iron oxyhydroxide. J. Colloid Interfac. Sci. 79: 209-221.

Calmano, W., W. Ahlf \& U. Förstner, 1988a. Study of metal sorption/desorption processes on competing sediment phases with a multichamber device. Envir. Geol. Wat. Sci. 11: $77-84$.

Calmano, W., W. Ahlf, H. Baade \& U. Förstner, 1988b. Transfer of heavy metals from polluted sediments under changing environmental conditions. In: M. Astruc \& J. N. Lester (eds), Heavy Metals in the Hydrological Cycle. Selper Ltd., London: 501-506.

Förstner, U., W. Ahlf, W. Calmano \& C. Sellhorn, 1984. Schwermetall/Feststoff-Wechselwirkungen in Ästuargewässern: Sorptionsexperimente mit organischen Partikeln. Vom Wasser 63: 141-156.

Förstner, U., W. Ahlf \& W. Calmano, 1989. Studies on the transfer of heavy metals between sedimentary phases with a multichamber device: Combined effects of salinity and redox variation. Mar. Chem. 28: 145-158.

Gamble, D. A., A. W. Underwood \& C. H. Langford, 1980. Copper(II) titration of fulvic acid ligand sites with theoretical potentiometric and spectrophotometric analysis. Analyt. Chem. 52: 1901-1908.

Leckie, J. O., 1986. Adsorption and transformation of trace element species at sediment/water interfaces. In: M. Bernhard, F. E. Brinckman \& P. J. Sadler (eds), The Importance of Chemical Speciation in Environmental Processes. Springer-Verlag Berlin, London, New York: 237-254. 